\title{
Evaluation of micro-energy dispersive $X$-ray fluorescence and histochemical tests for aluminium detection in plants from High Altitude Rocky Complexes, Southeast Brazil
}

\author{
NAIARA V. CAMPOS ${ }^{1}$, TIAGO A.R. PEREIRA ${ }^{1}$, MARIANA F. MACHADO ${ }^{1}$, \\ MARCELO B.B. GUERRA ${ }^{2}$, GLÁUCIA S. TOLENTINO ${ }^{1}$, JOSIANE S. ARAÚJO ${ }^{1}$, \\ MAÍRA Q. REZENDE ${ }^{3}$, MARIA CAROLINA N.A. DA SILVA ${ }^{1}$ and CARLOS E.G.R. SCHAEFER ${ }^{2}$ \\ ${ }^{1}$ Departamento de Biologia Vegetal, Universidade Federal de Viçosa, \\ Av. Peter Henry Rolfs, s/n, 36570-900 Viçosa, MG, Brasil \\ ${ }^{2}$ Departamento de Solos, Universidade Federal de Viçosa, \\ Av. Peter Henry Rolfs, s/n, 36570-900 Viçosa, MG, Brasil \\ ${ }^{3}$ Departamento de Entomologia, Universidade Federal de Viçosa, \\ Av. Peter Henry Rolfs, s/n, 36570-900 Viçosa, MG, Brasil
}

Manuscript received on July 13, 2012; accepted for publication on May 8, 2013

\begin{abstract}
The soils developed under High Altitude Rocky Complexes in Brazil are generally of very low chemical fertility, with low base saturation and high exchangeable aluminium concentration. This stressful condition imposes evolutionary pressures that lead to ecological success of plant species that are able to tolerate or accumulate high amounts of aluminium. Several analytical methods are currently available for elemental mapping of biological structures, such as micro-X-ray fluorescence ( $\mu$-EDX) and histochemical tests. The aim of this study was to combine $\mu$-EDX analysis and histochemical tests to quantify aluminium in plants from High Altitude Rocky Complexes, identifying the main sites for Al-accumulation. Among the studied species, five showed total Al concentration higher than $1000 \mathrm{mg} \mathrm{kg}^{-1}$. The main Al-hyperaccumulator plants, Lavoisiera pectinata, Lycopodium clavatum and Trembleya parviflora presented positive reactions in the histochemical tests using Chrome Azurol and Aluminon. Strong positive correlations were observed between the total Al concentrations and data obtained by $\mu$-EDX analysis. The $\mu$-EDX analysis is a potential tool to map and quantify $\mathrm{Al}$ in hyperaccumulator species, and a valuable technique due to its non-destructive capacity. Histochemical tests can be helpful to indicate the accumulation pattern of samples before they are submitted for further $\mu$-EDX scrutiny.
\end{abstract}

Key words: Al-hyperaccumulator plants, aluminon, chrome azurol, High Altitude Rocky Complexes, $\mu$-EDX.

\section{INTRODUCTION}

The soils of tropical and subtropical regions commonly exhibit acidic properties due to intense leaching, which results in removal of negative

Correspondence to: Tiago Augusto Rodrigues Pereira

E-mail: tiagoarp@gmail.com charges and retention of compounds containing iron and aluminium (Echart and Molina 2001). About $30 \%$ of the world's soils are acidic, with $\mathrm{pH}$ $\leq 5.5$, presenting low levels of organic matter and base saturation, and high levels of exchangeable aluminium $\left(\mathrm{Al}^{3+}\right.$ ) (Hartwig et al. 2007). In Brazil, 
soils derived from granitic and gneiss rocky outcrops of the Serra da Mantiqueira are associated with high $\mathrm{Al}^{3+}$ contents (Benites et al. 2007).

High soil acidity increases aluminium availability, which, in turn, can affect Al-sensitive plants causing both root growth inhibition and thickening of root epidermis (Ciamporová 2002, Vitorello et al. 2005). Low nutrient availability combined with high aluminium concentrations in soil solution act as an important environmental stress agent (Larcher 2000, Grime 2001). The tolerance to high $\mathrm{Al}^{3+}$ concentrations is an ecological attribute that permits the occupation of a site qualified as inappropriate for Al-sensitive species (Jansen et al. 2002a). Some plants living in these environments can accumulate more than $1000 \mathrm{mg} \mathrm{kg}^{-1}$ of $\mathrm{Al}$ in their tissues, being called hyperaccumulator species (Baker 1981). Hyperaccumulator plants have mechanisms of aluminium resistance, such as synthesis of chelator agents and turnover of roots and leaves which have already reached high levels of aluminium (Cuenca and Herrera 1987, Cuenca and Medina 1990).

Melastomataceae, Rubiaceae, Asteraceae, Vochysiaceae and Myrtaceae contain a great number of taxa whose life histories are related to soils presenting high Al contents (Chenery and Sporne 1976, Haridasan 1988, Jansen et al. 2000, 2002a, b). Lycopodiaceae and Pteridaceae were previously described as pertaining to the aluminium accumulator families (Church 1888, Olivares et al. 2009). The chelation mechanism of these species is based on $\mathrm{Al}^{3+}$ retention by organic acids in celular compartments such as cell wall and vacuole (Taylor 1991, Delhaize and Ryan 1995, Shen et al. 2002).

The study of metal distribution patterns in plant tissues can clarify accumulation processes in tolerant species, simultaneously quantifying and mapping the content of chemical elements (Moradi et al. 2010). Methods commonly used for mapping studies in biological tissues are based on
$\mu$-EDX or Synchrotron radiation X-ray fluorescence (West et al. 2009, Majumdar et al. 2012), microproton-induced X-ray emission (Lyubenova et al. 2012), and also laser-based methods such as laser ablation inductively coupled plasma mass spectrometry (Guerra et al. 2011, Qin et al. 2011) and laser induced breakdown spectroscopy (Galiová et al. 2007, Santos Jr. et al. 2012, Piñon et al. 2013).

$\mathrm{X}$-ray fluorescence analysis (XRF) is a fast and non-destructive method which has several applications (Saisho and Hashimoto 1996, West et al. 2009). Although the common detection limit of the XRF technique ranges from $\mathrm{mg} \mathrm{kg}^{-1}$ to $\% \mathrm{ww}^{-1}$ (Saisho and Hashimoto 1996), it can be successfully applied to hyperaccumulator species tissues (Memon et al. 1981, Cuenca et al. 1991, Robinson et al. 2003, Broadhurst et al. 2004, Berazain et al. 2007, Turnau et al. 2007, Tolrà et al. 2011). In order to perform quantitative measurements, calibration can be done by the linear relationship between the intensity of X-ray emission of a target element and its concentration previously determined by a reference method. The quality of the XRF data can be evaluated by the correlation between the XRF intensity and the reference values using figures of merit such as linear correlation factor, standard error of prediction (SEP), confidence intervals and bias (Paltridge et al. 2012).

Applying histochemical and chemical techniques for detection of compounds of interest, such as potentially toxic metals, can complement the data obtained from X-ray microanalysis, since they are useful for locating discrete quantities of chemical elements in biological tissues (Pearse 1972, 1988, Krishnamurthy 1998). Several reagents are used in $\mathrm{Al}$ histolocalization, such as Hematoxylin, Aluminon, Chrome Azurol, Pyrocatecol and Azurine (Baker 1962, Denton et al. 1984, Clark and Krueger 1985, Haridasan et al. 1986, Cotta et al. 2008). 
In this context, this study aimed to combine $\mu$-EDX analysis and histochemical tests to quantify aluminium in plants from High Altitude Rocky Complexes, characterizing, furthermore, the main sites for Al-accumulation in shoots.

According to our knowledge this is the first study reporting aluminium detection in hyperaccumulator plants from High Altitude Rocky Complexes using both $\mu$-EDX apparatus and histochemical tests.

\section{MATERIALS AND METHODS}

\section{STUDY AREA}

\section{Serra do Brigadeiro State Park}

The Serra do Brigadeiro State Park is located in Araponga (State of Minas Gerais, Brazil, 20 $0^{\circ} 40^{\prime} \mathrm{S}$ and $42^{\circ} 26^{\prime} \mathrm{W}$ ) in Serra da Mantiqueira massif. According to Köeppen, the climate is mesothermal $(\mathrm{CWb})$. The mean annual rainfall and air temperature are about $1500 \mathrm{~mm}$ and $15^{\circ} \mathrm{C}$, respectively (Benites et al. 2001).
The High Altitude Rocky Complexes are located in the highest points of the Serra da Mantiqueira massif, in areas above $1500 \mathrm{~m}$, being associated with igneous and metamorphic parent materials (Vasconcelos 2011). The vegetation cover is related to soils with high aluminium saturation and low calcium and magnesium contents (Benites et al. 2001).

\section{STUdiEd SPECIES}

Ten plant species were sampled: Marcetia taxifolia, Lavoisiera pectinata, Tibouchina heteromalla and Trembleya parviflora (Melastomataceae); Baccharis trimera and Eremanthus erythropappus (Asteraceae); Nanuza plicata and Vellozia variegata (Velloziaceae); Myrsine umbellata (Myrsinaceae) and Lycopodium clavatum (Lycopodiaceae). Samples of three individuals of each species were collected. Soil and vegetation classification of sampling sites are described in Table I (B.V. Tinti et al., unpublished data).

TABLE I

Soils and vegetation types studied at the Serra do Brigadeiro State Park.

\begin{tabular}{|c|c|c|c|c|c|}
\hline SOIL & SPECIES & FAMILY & VEGETATION & SOIL & {$\left[\mathbf{A l}^{3+}\right]^{*}$} \\
\hline 1 & Lavoisiera pectinata Cogn. & Melastomataceae & $\begin{array}{l}\text { Monodominant wet } \\
\text { scrub Lavoisiera }\end{array}$ & $\begin{array}{l}\text { Dystric Humic } \\
\text { Cambisol }\end{array}$ & 1.3 \\
\hline \multirow{5}{*}{2} & Eremanthus erythropappus (DC.) MacLeish & Asteraceae & Dwarf forest /scrub & $\begin{array}{c}\text { Spodic Sapric } \\
\text { Organosol }\end{array}$ & 3.7 \\
\hline & Marcetia taxifolia (A. St.-Hil.) DC. & Melastomataceae & Dwarf forest /scrub & $\begin{array}{c}\text { Spodic Sapric } \\
\text { Organosol }\end{array}$ & 3.7 \\
\hline & Myrsine umbellata Mart. & Myrsinaceae & Dwarf forest /scrub & $\begin{array}{c}\text { Spodic Sapric } \\
\text { Organosol }\end{array}$ & 3.7 \\
\hline & Tibouchina heteromalla Cogn. & Melastomataceae & Dwarf forest /scrub & $\begin{array}{c}\text { Spodic Sapric } \\
\text { Organosol }\end{array}$ & 3.7 \\
\hline & Trembleya parviflora (D. Don) Cogn. & Melastomataceae & Dwarf forest /scrub & $\begin{array}{c}\text { Spodic Sapric } \\
\text { Organosol }\end{array}$ & 3.7 \\
\hline \multirow{3}{*}{3} & Baccharis trimera (Less) DC. & Asteraceae & Wet grassy field & $\begin{array}{l}\text { Dystric Humic } \\
\text { Cambisol }\end{array}$ & 1.4 \\
\hline & Nanuza plicata (Mart.) L.B.Sm. \& Ayensu & Velloziaceae & Wet grassy field & $\begin{array}{l}\text { Dystric Humic } \\
\text { Cambisol }\end{array}$ & 1.4 \\
\hline & Vellozia variegata Goethart \& Henrard & Velloziaceae & Wet grassy field & $\begin{array}{c}\text { Dystric Humic } \\
\text { Cambisol }\end{array}$ & 1.4 \\
\hline 4 & Lycopodium clavatum $\mathrm{L}$. & Lycopodiaceae & Scarpment scrub & Folic Organosol & 1.4 \\
\hline
\end{tabular}

* Exchangeable Al concentration $\left(\mathrm{cmolc} \mathrm{dm}^{-3}\right)$ at the $0-20 \mathrm{~cm}$ horizon. 


\section{AL-LocALIZATION IN PLANT TISSUES}

Samples of stems and leaves from all plant species were fixed using a solution composed of formaldehyde and acetic acid (FAA) $50 \%\left(\mathrm{v} \mathrm{v}^{-1}\right)$, dehydrated through an ethanol series (Johansen 1940) and freehand sectioned with a razor blade. Subsequently, the sections were submitted to a histochemical test using Chrome Azurol (reaction time: 15 minutes). Sections that showed positive reactions, evidenced by the blue color, were subjected to new tests with Chrome Azurol and Aluminon for 30 minutes. For Aluminon test the intense red color is identified as a positive reaction.

Photographs were taken using a light microscope (Olympus AX70TRF, Olympus Optical, Tokyo, Japan) coupled with a U-Photo Camera system (Spot Insightcolour 3.2.0, Diagnostic Instruments inc. New York, USA).

\section{AL-DETERMINATION IN PLANT MATERIAL}

\section{Determination of total Al concentration using ICP OES}

Samples of plant material $(\mathrm{n}=10)$ were oven-dried at $70{ }^{\circ} \mathrm{C}$, until constant weight, and were powdered with the help of a knife mill.

Powdered samples were digested, in triplicate, with nitro-perchloric solution in an electric plate following procedure described by Tedesco et al. (1995). A comparative wet-based decomposition procedure based on nitric acid and hydrogen peroxide using a microwave-assisted digestion was also performed as described by Guerra et al. (2013).

Determination of total $\mathrm{Al}$ concentration in acid extracts was performed using inductively coupled plasma optical emission spectrometry with dual-view configuration (Perkin Elmer, Shelton, CT, EUA). Operational conditions of ICP OES measurements were described in Table II.

$\mu-E D X$ analysis

Samples which showed higher Al concentration were selected and analyzed using micro-energy dispersive
TABLE II

Operational conditions in ICP OES determinations.

\begin{tabular}{cc}
\hline Instrumental parameters & $\begin{array}{c}\text { Operational } \\
\text { conditions }\end{array}$ \\
\hline Generator frequency $(\mathrm{MHz})$ & 40 \\
Spray chamber & Cyclonic \\
RF applied power $(\mathrm{kW})$ & 1.3 \\
Integration time $(\mathrm{s})$ & 1.0 \\
Plasma gas flow rate $(\mathrm{L} / \mathrm{min})$ & 15 \\
Auxiliary gas flow rate $(\mathrm{L} / \mathrm{min})$ & 1.5 \\
Nebulizer gas flow rate $(\mathrm{L} / \mathrm{min})$ & 0.8 \\
Sampling flow rate $(\mathrm{mL} / \mathrm{min})$ & 1.5 \\
Al I (nm) & 396.152 \\
\hline
\end{tabular}

X-ray fluorescence technique ( $\mu$-EDX-1300, Shimadzu, Kyoto, Japan). The usefulness of this technique in determination of total $\mathrm{Al}$ concentration and mapping studies on the raw sample material was evaluated.

Pellets of powdered plant samples (particle size lower than $250 \mu \mathrm{m}$ ) were prepared after applying $10 \mathrm{t} \mathrm{cm}^{-2}$ (Perkin Elmer, Waltham, MA, EUA) pressure during 5 minutes on $0.15 \mathrm{~g}$ of dried material. On each pellet 10 points were randomly selected to be analyzed by $\mu$-EDX apparatus. The operational conditions were described in Table III.

A linear regression model was adjusted to correlate Al total concentration determined by ICP OES and $\mu$-EDX intensity (cps $\mu \mathrm{A}^{-1}$ ) as recommended by Guerra et al. 2013. By using this linear regression model, it was possible to evaluate the $\mathrm{Al}$ distribution on the aerial parts of pre-selected plants. Samples of leaves, with or without the stem, were oven dried at $70{ }^{\circ} \mathrm{C}$ and fixed on paper supports using adhesive tape. For each plant species, different parts of leaves and stem were analyzed and, for each part, five points were randomly selected.

STATISTICAL ANALYSIS

The data was analyzed using analysis of variance (ANOVA), followed by Tukey test at 5\% signifi- 
TABLE III

Operational conditions in $\mu$-EDX analysis.

\begin{tabular}{cc}
\hline Instrumental parameters & Operational conditions \\
\hline Measuring principle & $\begin{array}{c}\text { X-ray fluorescence } \\
\text { spectrometry }\end{array}$ \\
\hline Measuring method & $\begin{array}{c}\text { Energy-dispersive } \\
\text { X-ray analysis }\end{array}$ \\
\hline Working distance $(\mathrm{mm})$ & 1.5 \\
\hline Detector & $\mathrm{Si}(\mathrm{Li})$ semiconductor \\
\hline Irradiated diameter $(\mu \mathrm{m})$ & 50 \\
\hline Measurement time $(\mathrm{s})$ & 200 \\
\hline $\begin{array}{c}\text { Analyzed spectra } \\
\text { region }(\mathrm{keV})\end{array}$ & $0.00-4.00$ \\
\hline Measuring atmosphere & $\mathrm{Atmospheric}$ air \\
\hline X-ray power unit & $\mathrm{X}$-ray tube $(\mathrm{Rh}$ target $)$ \\
\hline Monitored peak & $\mathrm{Al}(\mathrm{K} \alpha)-1.49 \mathrm{keV}$ \\
\hline Channel & $\mathrm{Na}-\mathrm{Sc}$ \\
\hline Electric voltage $(\mathrm{kV})$ & 15 \\
\hline Electric current $(\mu \mathrm{A})$ & 500 \\
\hline
\end{tabular}

cance level. All analyses were performed using R 2.13 software (R Development Core Team 2006) and were followed by residual analyses to check for the suitability of the models (Crawley 2007).

\section{RESULTS}

\section{AL-LocAlizaTion In PLANT Tissues}

Among the analyzed species, seven presented negative result for $\mathrm{Al}$ presence using Chrome Azurol (Myrsine umbellate, Eremanthus erythropappus, Vellozia variegata, Baccharis trimera, Tibouchina heteromalla, Nanuza plicata and Marcetia taxifolia). Otherwise, three species (Lavoisiera pectinata, Trembleya parviflora and Lycopodium clavatum) showed a positive reaction for Chrome Azurol and Aluminon, which indicates higher Al concentration in the stem or leaf tissues (Figure 1). The positive reaction to Chrome Azurol was noted in primary walls, epidermal cells, parenchyma and phloem. A negative reaction to Chrome Azurol was observed in secondary cell walls including those of xylem vessels and sclerenchyma fibers. Aluminon results showed the same pattern observed for Chrome Azurol.
The reaction in L. pectinata was markedly evident in the cuticle layer on both sides of the leaf epidermis cells (Figure 1A-C). In T. parviflora a negative reaction to Chrome Azurol was noted in palisade parenchyma cells (Figure 1E) even though a positive reaction to Aluminon had been detected (Figure 1D). A positive reaction to Aluminon was observed around the vascular cylinder in $L$. clavatum (Figure 1G).

\section{AL-Determination in Plant Material}

\section{Total Al concentration}

The average of the total $\mathrm{Al}$ concentration in plants $\left(\mathrm{mg} \mathrm{kg}^{-1}\right)$ was as follows: Vellozia variegata (216), Myrsine umbellata (297), Nanuza plicata (344), Marcetia taxifolia (641), Baccharis trimera (749), Eremanthus erythropappus (1149), Tibouchina heteromalla (2000), Trembleya parviflora (3878), Lavoisiera pectinata (8589) and Lycopodium clavatum (9049). The following samples: $L$. clavatum, L. pectinata and T. parviflora were selected for X-ray fluorescence analysis due the highest $\mathrm{Al}$ concentrations observed in these species.

\section{$\mu$-EDX results}

Micro-energy dispersive X-ray fluorescence analysis revealed significant differences between the studied species after evaluating the data obtained from $\mathrm{Al}$ peak intensities $\left(\mathrm{F}_{2.27}=14.323 ; \mathrm{p}<0.0001\right)$ at 1.49 $\mathrm{keV}$ (Ka line). L. clavatum (0.029 $\left.\mathrm{cps} \mu \mathrm{A}^{-1}\right)$ and $L$.

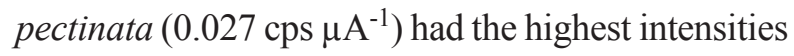
and its averages were not significantly different $\left(\mathrm{F}_{2,28}=0.245, \mathrm{p}=0.62\right)$ (Figure 2). T. parviflora had a mean significantly lower $\left(0.0123 \mathrm{cps} \mu \mathrm{A}^{-1}\right)$. Linear regression model, adjusted in order to verify the correlation between the total $\mathrm{Al}$ concentrations and the intensity values, revealed a high linear correlation factor ( $\mathrm{r}^{2}$ higher than 0.99$)$.

The highest $\mathrm{Al}$ concentrations in leaves, obtained by $\mu$-EDX analysis were observed in L pectinata $\left(F_{2,9}=31.84, p=0.002\right)$. This result, however, 

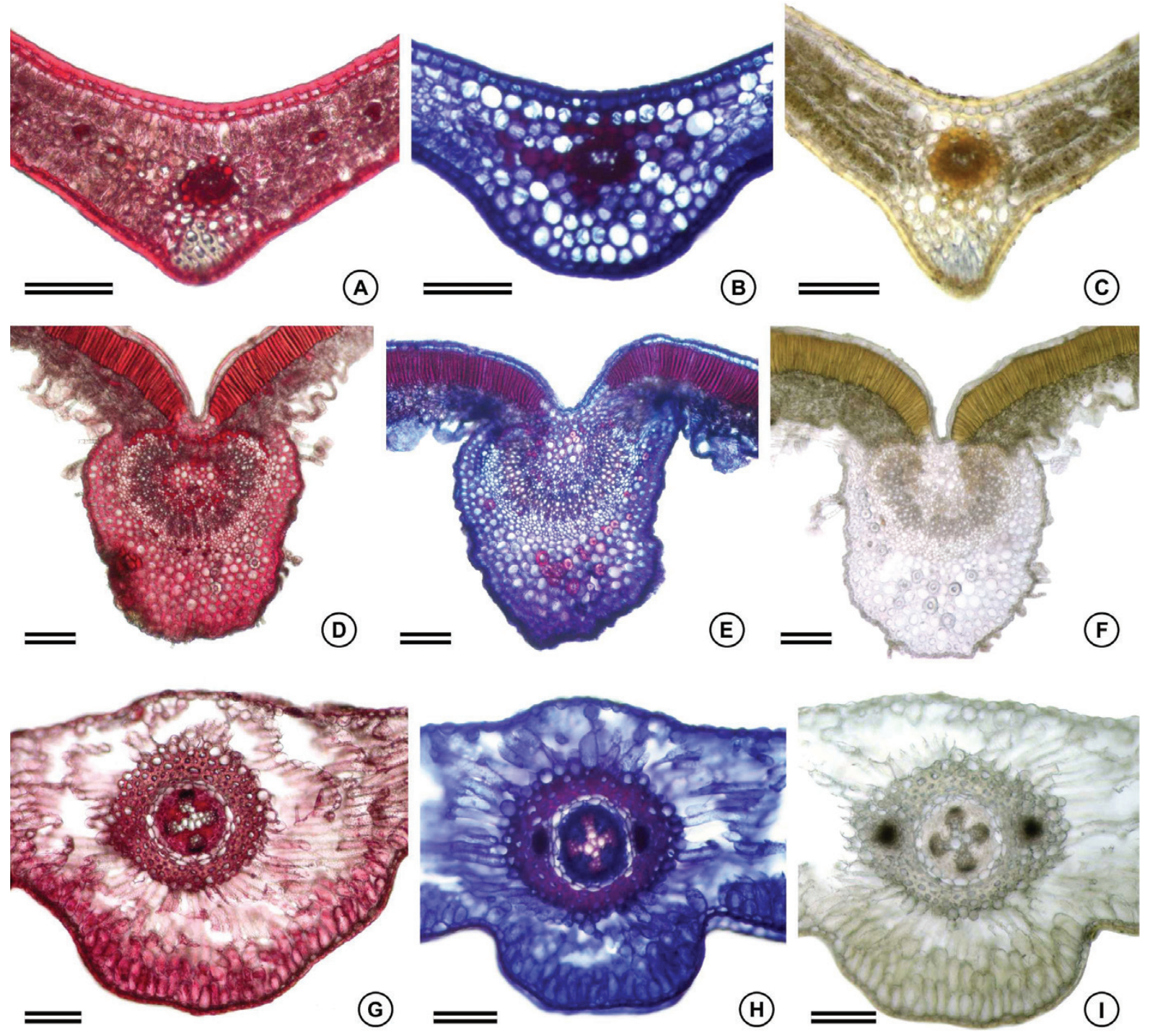

Figure 1 - Cross sections of leaves of Lavoisiera pectinata (A-C), Trembleya parviflora (D-F) and stem of Lycopodium clavatum (G-I). A, D and G. Tissues treated with Aluminon. B, E and H. Tissues treated with Chrome Azurol. C, F and I. Blank test. Bars length $=100 \mu \mathrm{m}$.

underestimate the concentration of $\mathrm{Al}$ in $L$. clavatum when the average concentration in the points were compared with the total $\mathrm{Al}$ concentration obtained by ICP OES determination. In $L$. pectinata and $L$. clavatum, there were no differences in $\mathrm{Al}$ concentrations among the average concentrations of the analyzed regions and the ICP OES results $\left(\mathrm{F}_{2,14}=0.51\right.$, $\mathrm{p}=0.61 ; \mathrm{F}_{2,29}=0.06, \mathrm{p}=0.81 ;$ respectively). In $T$. parviflora the highest $\mathrm{Al}$ concentration was observed in the midvein $\left(F_{2,32}=20.00, p<0.0001\right)$ (Figure 3).

\section{DISCUSSION}

The occurrence of plant species in soils with high availability of $\mathrm{Al}^{3+}$ suggests physiological mechanisms that define them as stress-tolerant (Chenery and Sporne 1976, Grime 2001, Jansen et al. 2002a, Ramírez-Rodriguez et al. 2005). Hyperaccumulator plant species can be found in approximately 45 different families, being an intrinsic characteristic to at least 18 of them (Jansen et al. 2002a). 


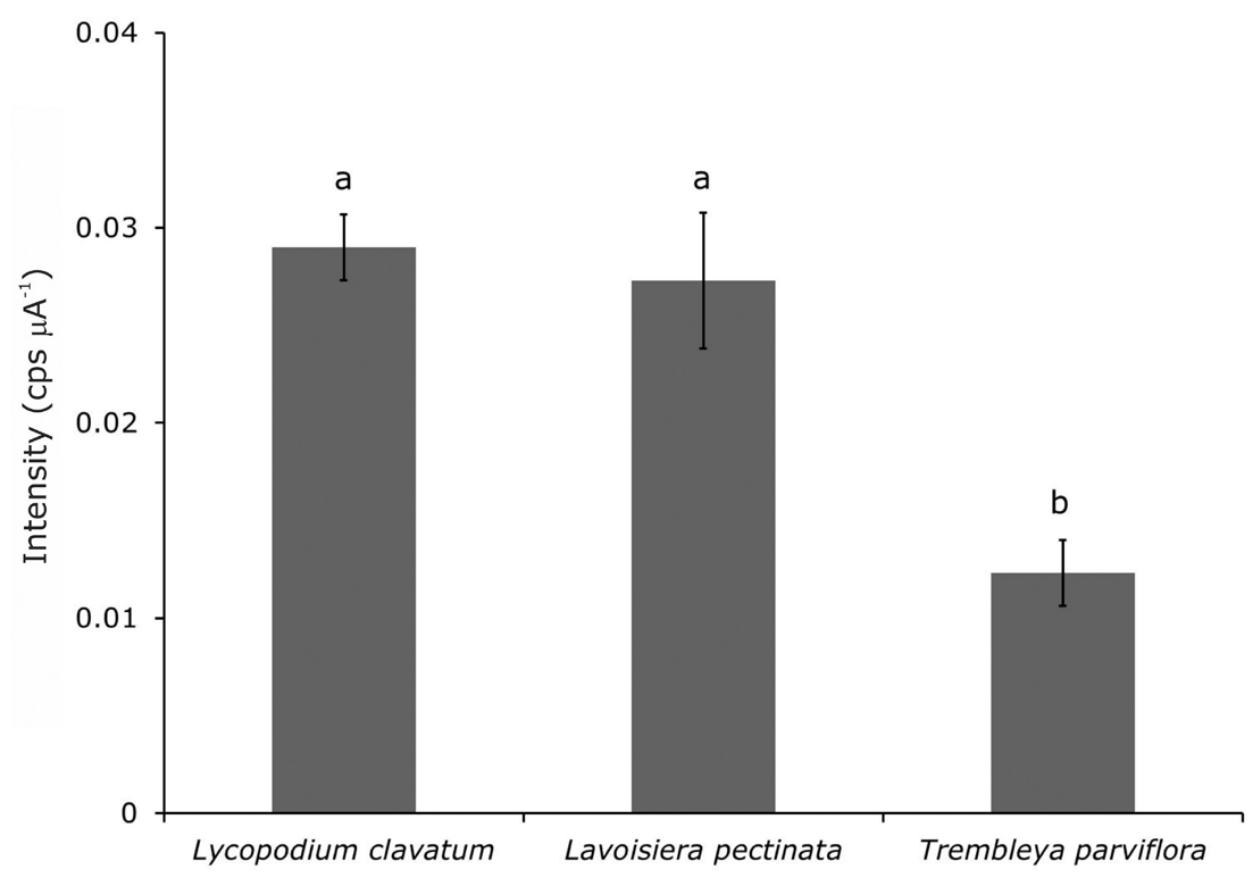

Figure 2 - Micro-energy dispersive X-ray spectrometry data of three different plant species in pellet formats $\left(F_{2,27}=14.323 ; p<0.0001\right)$. Different letters represent significant differences of detected intensities.

Among the sampled species, Lycopodium clavatum, Lavoisiera pectinata, Trembleya parviflora, Tibouchina heteromalla and Eremanthus erythropappus showed Al concentrations higher than $1000 \mathrm{mg} \mathrm{kg}^{-1}$, which characterize them as hyperaccumulator species (Baker 1981). Lavoisiera pectinata, T. parviflora and T. heteromalla belong to Melastomataceae family, which comprises the highest number of Al-accumulator plant species (Jansen et al. 2002b). The aluminium concentration found in L. clavatum in our study was higher than that observed on aerial parts of plants living in high Al-concentration soils by Olivares et al. (2009). According to Haridasan and Araújo (1988), Eremanthus glomerulatus shows low aluminium concentration (150 mg kg-1), although other Asteraceae were described as hyperaccumulator species (Geoghegan and Sprent 1996). The low aluminium concentrations observed in Marcetia taxifolia, Nanuza plicata, Vellozia variegata, Myrsine umbellata and Baccharis trimera could be related to exclusion mechanisms or compartmentalization of this element in underground organs (Jansen et al. 2002a, Kochian et al. 2005, Hartwig et al. 2007).

Some Al-accumulating plants releases organic acids to chelate $\mathrm{Al}^{3+}$ or maintain it within cells compartments, such as cell wall or vacuole (Taylor 1991, Delhaize and Ryan 1995, Shen et al. 2002). Among cell wall components, pectates are considered the main linkers to $\mathrm{Al}^{3+}$ (Chang et al. 1999, Blamey 2001). The histochemical tests indicated the primary cell walls as preferential sites of aluminium accumulation, possibly due to high content of pectates in relation to xylem secondary walls (Evert 2006).

The intense color of the cuticle and bundle sheath cell walls in $L$. pectinata suggests a feasible mechanism whose function would be the protection of photosynthetic apparatus, as observed for Erica andevalensis by Turnau et al. (2007). The positive response observed in chlorenchyma of L. clavatum and T. parviflora suggests that chloroplasts could have an important role in accumulation of aluminium. High aluminium concentration observed in 


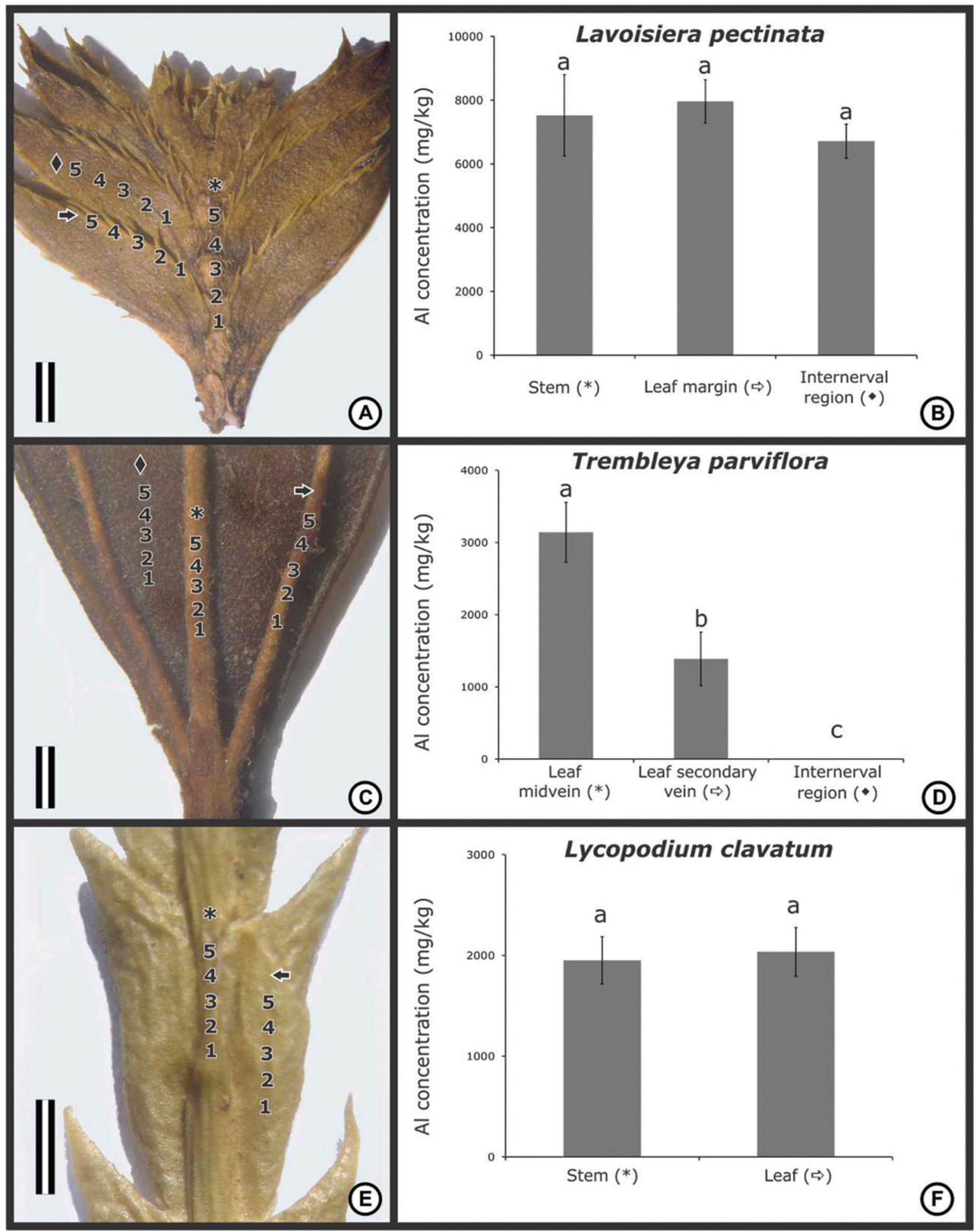

Figure 3 - Aluminium concentration evaluated by micro-energy dispersive X-ray spectrometry in dry leaves of three different plant species $\left(\mathrm{F}_{2,9}=31.84 ; \mathrm{p}=0.002\right)$. Different letters represent significant differences of aluminium concentration. A-B: Lavoisiera pectinata. C-D: Trembleya parviflora. E-F: Lycopodium clavatum. A, C and E indicate the selected points analyzed in leaves and stem. Bars length $=1 \mathrm{~mm}$. 
the mesophyll cells of pre-senescent leaves of Richeria grandis is possibly stored in the vacuole and chloroplasts (Cuenca et al. 1991).

Tests with Aluminon and Chrome Azurol represent techniques easily applied for preliminary studies, since they indicated, in this study, species with Al concentrations above $3000 \mathrm{mg} \mathrm{kg}^{-1}$. However, the histochemical tests are qualitative methods which are not able to discriminate between different $\mathrm{Al}$ concentrations. Aluminon is not a specific reagent for $\mathrm{Al}^{3+}$ detection, and the intensity of its reaction can be influenced by other ions such as $\mathrm{Fe}^{3+}$ or $\mathrm{Be}^{2+}$, as well as other factors, such as cell type or intracellular pH (Clark and Krueger 1985). These limitations can explain the differences observed among the histochemical tests results.

Data obtained from pellets subjected to $\mu$-EDX analyses were well correlated with the total Al concentrations obtained by ICP OES measurements, exhibiting linear correlation factor higher than 0.99 , revealing that $\mu$-EDX method is a suitable tool for $\mathrm{Al}$ quantification in plant samples.

The $\mu$-EDX results obtained on dried leaves were consistent with those observed in histochemical tests, which showed a more homogeneous Al distribution in leaves of $L$. pectinata and L. clavatum. The low values obtained for $\mathrm{Al}$ in $L$. clavatum can be explained by a number of intercellular spaces presented in the leaf and stem of this specie, which can hamper the $\mu$-EDX application due to its small spot size, $50 \mu \mathrm{m}$. The differences between the sampling points in $T$. parviflora may be related to higher cell density in leaf veins.

The feasibility of XRF technique on direct determination of elements in plant tissues was already demonstrated in several studies, such as Anjos et al. (2002), Hokura et al. (2005) and Marguí et al. (2009).

Despite all well documented limitations, mainly those related to matrix effects, the XRF technique is a fast and non-destructive method that can be successfully used in simultaneous determination of all target elements without requirement of laborious sample preparation steps (Saisho and Hashimoto 1996, Torok et al. 1998). The use of additional techniques, such as histochemical tests, can be used to complement data obtained from $\mu$-EDX analysis.

\section{CONCLUSIONS}

Micro-energy dispersive X-ray fluorescence appears to be a suitable technique to Al quantification in pellets of ground plant tissues as well as for mapping studies in preserved dried leaves. Among the main advantages of this technique, we can mention (i) the low amount of sample required, (ii) its non-destructive capacity and (iii) achievement of reliable data without using expensive and hazardous chemicals.

Histochemical tests can be helpful for screening purposes of main bioaccumulation sites of samples before they are submitted to further $\mu$-EDX scrutiny.

\section{ACKNOWLEDGMENTS}

We would like to thank Bruno Tinti for helping us during sampling and for providing soil data. We wish to thank the Fundação de Amparo à Pesquisa do Estado de São Paulo (FAPESP 2012/16203-5) and Fundação de Amparo à Pesquisa do Estado de Minas Gerais (FAPEMIG 12070/2009) for financial support and grants.

\section{RESUMO}

Solos associados aos Complexos Rupestres de Altitude no Brasil destacam-se pela baixa fertilidade química, baixa saturação de bases e elevados teores de alumínio trocável. Esta condição estressante impõe pressões evolutivas que determinam o sucesso ecológico de espécies capazes de tolerar ou acumular grandes quantidades de alumínio. Vários métodos analíticos são utilizados para mapeamento de elementos químicos em estruturas biológicas, como microfluorescência de raios-X ( $\mu$-EDX) e testes histoquímicos. O objetivo do presente trabalho foi combinar a $\mu$-EDX e testes histoquímicos para quantificar 
o teor de $\mathrm{Al}$ em espécies vegetais de Complexos Rupestres de Altitude, e identificar os principais sítios de bioacumulação de Al. Cinco das espécies investigadas apresentaram concentração total de $\mathrm{Al}$ maior que $1000 \mathrm{mg} \mathrm{kg}^{-1}$. As principais hiperacumuladoras de Al, Lavoisiera pectinata, Lycopodium clavatum e Trembleya parviflora, apresentaram reação positiva nos testes histoquímicos com Chrome Azurol e Aluminon. Alta correlação positiva foi observada entre as concentrações totais de $\mathrm{Al}$ e as magnitudes de sinal obtidas por $\mu$-EDX. A análise com o uso da $\mu$-EDX mostrou-se uma ferramenta promissora para mapear e quantificar Al em espécies hiperacumuladoras, constituindo uma importante técnica não destrutiva. Testes histoquímicos podem ser úteis na identificação de padrões de acumulação de Al em amostras vegetais antes de serem submetidas a uma minuciosa análise com a $\mu$-EDX.

Palavras-chave: plantas hiperacumuladoras de Al, aluminon, chrome azurol, Complexos Rupestres de Altitude, $\mu$-EDX.

\section{REFERENCES}

Anjos MJ, Lopes RT, Jesus EFO, Simabuco SM AND CESAREO R. 2002. Quantitative determination of metals in radish using X-ray fluorescence spectrometry. X-Ray Spectrom 31: 120-123.

BAKER AJM. 1981. Accumulators and excluders: Strategies in the response of plants to heavy metals. Journal of Plant Nutrition 3: 643-654.

BAKER JR. 1962. Experiments on the action of mordants 2. Aluminum-haematein. Q J Micr Sci 103: 493-517.

BENITES VM, SCHAEFER CEGR, MENDONÇA ES AND MARTINNeTO L. 2001. Caracterização da matéria orgânica e micromorfologia de solos sob Campos de Altitude no Parque Estadual da Serra do Brigadeiro. Rev Bras Ciênc Solo 25: 661-674.

Benites VM, SCHAEFER CEGR, Simas FNB AND SANTOS HG. 2007. Soils associated with rock outcrops in the Brazilian mountain ranges Mantiqueira and Espinhaço. Rev Bras Bot 30: 569-577.

Berazain R, De La Fuente V, Rufo L, Rodriguez N, AMILS R, DIEZ-GarRetas B, SANCHEZ-MATA D AND ASENSI A. 2007. Nickel localization in tissues of different hyperaccumulator species of Euphorbiaceae from ultramafic areas of Cuba. Plant and Soil 293: 99-106.

BLAMEY FPC. 2001. The role of the root cell wall in aluminum toxicity. In: AE N, ARIHARA J, OKADA $\mathrm{K}$ and SRINIVASAN A (Eds), Plant nutritent acquisition, Tokyo: Springer-Verlag, p. 201-226.
Broadhurst CL, Chaney RL, ANGLE JS, ERBE EF AND MAUGEL TK. 2004. Nickel localization and response to increasing $\mathrm{Ni}$ soil levels in leaves of the Ni hyperaccumulator Alyssum murale. Plant and Soil 265: 225-242.

Chang YC, Yamamoto Y AND Matsumoto H. 1999. Accumulation of aluminum in the cell wall pectin in cultured tobacco (Nicotiana tabacum L.) cells treated with a combination of aluminum and iron. Plant Cell Environ 22: 1009-1017.

CHENERY EM AND SPORNE KR. 1976. A note on the evolutionary status of aluminium-accumulators among Dicotyledons. New Phytologist 76: 551-554.

CHURCH AH. 1888. On the occurrence of aluminium in certain vascular cryptogams. P R Soc London 44: 121-129.

CiAmporovÁ M. 2002. Morphological and Structural Responses of Plant Roots to Aluminium at Organ, Tissue, and Cellular Levels. Biol Plant 45: 161-171.

ClARK RAAND KRUEGER GL. 1985. Review Article Aluminon: Its Limited Application as a Reagent for the Detection of Aluminum Species. J Histochem Cytochem 33: 729-732.

Cotta MG, ANDRADE LRM DE, GeEst AJV, Gomes ACMM, SOUZA CMD DE, ALMEIDA JD AND BARROS LMG. 2008. Diferenças entre hematoxilina e aluminon na detecção de alumínio em tecidos foliares de plantas nativas do Cerrado. IX Simpósio Nacional Cerrado. Desafios e estratégias para o equilíbrio entre sociedade, agronegócio e recursos naturais. 12 a 17 de outubro de 2008, Brasília (DF).

Crawley MJ. 2007. The R Book. Chichester: John Wiley \& Sons, $951 \mathrm{p}$.

CUENCA GAND HERRERAR. 1987. Ecophysiology of aluminium in terrestrial plants, growing in acid and aluminium-rich tropical soils. Ann Soc R Zool Belg 117: 57-74.

Cuenca G, Herrera R AND MÉRIDA T. 1991. Distribution of aluminium in accumulator plants by X-ray microanalysis in Richeria grandis Vahl leaves from a cloud forest in Venezuela. Plant Cell Environ 14: 437-441.

Cuenca G And Medina E. 1990. Aluminium tolerance in trees of a tropical cloud forest. PI \& Soil 125: 169-175.

DELHAIZE E AND RYAN PR. 1995. Aluminum toxicity and tolerance in plants. Plant Physiol 107: 315-321.

Denton J, Freemont AJ AND BALl J. 1984. Detection and distribution of aluminium in bone. J Clin Pathol 37: 136-142.

ECHART C AND MOLINA SC. 2001. Fitotoxicidade do alumínio: efeitos, mecanismo de tolerância e seu controle genético. Ciênc Rural 31: 531-541.

EVERT RF. 2006. Esau's Plant Anatomy, $3^{\text {rd }}$ ed., New Jersey: Wiley-Interscience, $601 \mathrm{p}$.

Galiová M, Kaiser J, Novotný K, SAmeK O, Reale L, MALINA R, PÁlENÍKOVÁ K, LIŠKA M, ČUdEK V, KANICKÝ V, OTRUBA V, POMA A AND TUCCI A. 2007. Utilization of laser induced breakdown spectroscopy for investigation of the metal accumulation in vegetal tissues. Spectrochim Acta B 62: 1597-1605.

GeOGHEGAN IE AND SPRENT JL. 1996. Aluminium and nutrient concentrations in species native to central Brazil Commun. Soil Sci Pl Anal 27: 2925-2934. 
GRIME JP. 2001. Plant strategies, vegetation processes, and ecosystem properties, $2^{\text {nd }}$ ed., Chichester: John Wiley \& Sons Ltd, $456 \mathrm{p}$.

Guerra MBB, AMARAsiriwardena D, SchaEFER CEGR, Pereira CD, SPIElmann AA, Nóbrega JA AND PEREIRAFILHO ER. 2011. Biomonitoring of lead in Antarctic lichens using laser ablation inductively coupled plasma mass spectrometry. J Anal At Spectrom 26: 2238-2246.

GuERra MBB, SchaEFER CEGR, CARVALHo GGA, SOUZA PF, SANTOS JR D, NunES LC AND KRUG FJ. 2013. Evaluation of micro-Energy Dispersive X-ray Fluorescence Spectrometry for the Analysis of Plant Materials. J Anal At Spectrom 28: 1096-1101.

HARIDASAN M. 1988. Performance of Miconia albicans (SW.) Triana, an aluminum-accumulating species, in acidic and calcareous soils. Comm Soil Sci Plant Anal 19: 1091-1103.

HARIDASAN M AND ARAÚJO GM. 1988. A comparison of the nutrient status of two forests on dystrofhic and mesotrophic soils in the Cerrado region of central Brazil. Comm Soil Sci Plant Anal 19: 1075-1089.

HARIDASAN M, PAVIANI TI AND SCHIAVINI I. 1986. Localization of aluminium in the leaves of some aluminiumaccumulating species. Plant Soil 94: 435-437.

Hartwig I, Oliveira AC, Carvalho FIF, Bertan I, Silva JAG, SChMidt DAM, VAlÉrio IP, Maia LC, FonseCa DNR AND REIS CES. 2007. Mecanismos associados à tolerância ao alumínio em plantas. Semina Ciências Agrárias 28: 219-228.

HoKura A, Onuma R, Kitajima N, NaKai I, Terada Y, AbE T, SAITO H AND YoshidA S. 2005. Cadmium Distribution in a Cadmium Hyperaccumulator Plant as Determined by Micro-XRF Imaging. Proc $8^{\text {th }}$ Int Conf X-ray Microscopy, p. 323-325.

JANSEN S, BROADLEY MR, RoBBRECHT E AND SMETS E. 2002a. Aluminum hyperaccumulation in Angiosperms: a review of its phylogenetic significance. Bot Rev 68: 235-269.

Jansen S, Dessein S, PIESSChaERT R, RobBrecht E AND SMETS E. 2000. Aluminium accumulation in leaves of Rubiaceae: Systematic and phylogenetic implications. Ann Bot 85: 91-101.

JANSEN S, Watanabe T AND SMEts E. 2002b. Aluminium accumulation in leaves of 127 species in Melastomataceae, with comments on the order Myrtales. Ann Bot 90: 53-64.

JOHANSEN DA. 1940. Plant microtechnique. New York: Mc Graw Hill, $532 \mathrm{p}$

Kochian LV, Pineros MA And Hoekenga OA. 2005. The physiology, genetics and molecular biology of plant aluminum resistance and toxicity. Plant Soil 274: 175-195.

KRISHNAMURTHY KV. 1998. Methods in plant histochemistry. S.Viswanathan, Chennai.

LARCHER W. 2000. Ecofisiologia vegetal. São Carlos: Rima, 531 p.

Lyubenova L, Pongrac P, Vogel-Mikuš K, MezeK GK, VAVPetič P, GrLJ N, KumP P, NeČEMER M, REgVAR M, PELICON P AND SCHRÖDER P. 2012. Localization and quantification of $\mathrm{Pb}$ and nutrients in Typha latifolia by micro-PIXE. Metallomics 4: 333-341.
Majumdar S, Peralta-Videa JR, Castillo-Michel H, Hong J, Rico CM AND GARDEA-TORRESDEY JL. 2012. Applications of synchrotron $\mu$-XRF to study the distribution of biologically important elements in different environmental matrices: A review. Anal Chim Acta 755: 1-16.

MARguí E, Queralt I AND Hidalgo M. 2009. Application of X-ray fluorescence spectrometry to determination and quantitation of metals in vegetal material. Trends Anal Chem 28: 362-372.

Memon AR, Chino M And Yatazawa M. 1981. Microdistribution of aluminum and manganese in the tea leaf tissues as revealed by X-ray microanalyzer. Commun Soil Sci Plant Anal 12: 441-452.

Moradi AB, Swoboda S, Robinson B, Prohaska T, KAESTNER A, OsWALd SE, WenZel WW AND SCHULin R. 2010. Mapping of nickel in root cross sections of the hyperaccumulator plant Berkheya coddii using laser ablation ICPMS. Environ Exp Bot 69: 24-31.

Olivares E, Pena E, Marcano E, Mostacero J, Aguiar G, BENITEZ M AND RENGIFO E. 2009. Aluminium accumulation and its relationship whit mineral plant nutrients in 12 pteridophytes from Venezuela. Environ Exp Bot 65: 132-141.

Paltridge NG, Milham PJ, ORTIZ-Monasterio JI, Velu G, YASMIN Z, PALMER LJ, GUILD GE AND STANGOULIS JCR. 2012. Energy-dispersive X-ray fluorescence spectrometry as a tool for zinc, iron and selenium analysis in whole grain wheat. Plant Soil 361: 261-269. [10.1007/s11104012-1423-0]

PEARSE AGE. 1972. Histochemistry: theoretical and applied, Vol. II, $3^{\text {rd }}$ ed., Churchill Livingstone, Edinburgh.

PEARSE AGE. 1988. Histochemistry: theoretical and applied, Vol. I, $4^{\text {th }}$ ed., Longman, London.

PIÑON V, MATEO MP AND NiCOlAs G. 2013. Laser-induced breakdown spectroscopy for chemical mapping of materials. Appl Spectrosc Rev 48: 357-383.

Qin Z, CARuso JA, Lai B, Matush A AND Becker JS. 2011. Trace metal imaging with high spatial resolution: Applications in biomedicine. Metallomics 3: 28-37.

R Development Core Team. 2006. R: A language and environment for statistical computing. R Foundation for Statistical Computing, Vienna, Austria.

RAMÍREZ-RODRÍGUEZ V, LÓPEZ-BUCIO J AND HERRERAEstrella L. 2005. Adaptative responses in plants to nonoptimal soil $\mathrm{pH}$. In: JENKS MA and HASEGAWA PM (Eds), Plant abiotic stress. Oxford: Blackwell Publishing, p. 145-170.

RoBINSON BH, LOMBI E, ZHAO FJ AND MCGRATH SP. 2003. Uptake and distribution of nickel and other metals in the hyperaccumulator Berkheya coddii. New Phytologist 158: 279-285.

SAISHO H AND HASHImoto H. 1996. X-ray fluorescense analysis. In: SAISHO H AND GOHSHI Y (Eds), Applications of Synchontron Radiation to Materials Analysis. Amsterdam: Elsevier, p. 79-169. 
SAntos JR D, Nunes LC, CARVAlho GGA, GOMES MS, SOUZA PF, LEME FO, SANTOS LGC AND KRUG FJ. 2012. Laserinduced breakdown spectroscopy for analysis of plant materials: A review. Spectrochim Acta B 71-72: 3-13.

Shen R, MA J, Kyo M And Iwashita T. 2002. Compartmentation of aluminium in leaves of an Al-accumulator, Fagopyrum esculentum Moench. Planta 215: 394-398.

TAYLOR GJ. 1991. Current views of the aluminum stress response: the physiological basis of tolerance. In: RANDALL DD, BLEVINS DG and MILES CD (Eds), Current Topics in Plant Biochemistry Physiology, Columbia: Missouri, v.10, p. 57-93.

Tedesco MJ, Gianello C, Bissani CA, Bohnen H and VolKWEISS SJ. 1995. Análise de solo, plantas e outros materiais. Porto Alegre: UFRGS, 174 p.

TOLRÀ R ET AL. 2011. Localization of aluminium in tea (Camellia sinensis) leaves using low energy X-ray fluorescence spectro-microscopy. J Plant Res 124: 165-172.
TOROK SB, LABAR J, Schmeling M AND VAN GRIEKEN RE. 1998. X-ray spectrometry. Anal Chem 70: 495-517.

Turnau K, Henriques FS, ANIELSKa T, RENKER C AND BUSCOT F. 2007. Metal uptake and detoxification mechanisms in Erica andevalensis growing in a pyrite mine tailing. Environ Exp Bot 61: 117-123.

VASCONCELOS MF. 2011. O que são campos rupestres e campos de altitude nos topos de montanha do Leste do Brasil? Rev Bras Bot 34: 241-246.

Vitorello VA, CAPALDI FR AND STEFANUTO VA. 2005 Recent advances in aluminum toxicity and resistance in higher plants. Braz J Plant Physiol 17: 129-143.

West M, Ellis AT, Potts PJ, Streli C, Vanhoof C, WEGRZYNEK D AND WOBRAUSCHEK P. 2009. Atomic spectrometry update. X-Ray fluorescence spectrometry. J Anal Spectrom 24: 1289-1326. 